\title{
PRESUPPOSITION FOUND IN THE BBC NEWS: CORONA VIRUS IN INDONESIA
}

\author{
Balqis Majesty Wahana ${ }^{1}$, \\ Putera Batam University (UPB), Batam, Kepri, Indonesia \\ pb181210018@upbatam.ac.id \\ Ambalegin ${ }^{2}$ \\ Putera Batam University (UPB), Batam, Kepri, Indonesia \\ Ambalegin@puterabatam.ac.id \\ Nurma Dhona Handayani ${ }^{3}$ \\ Putera Batam University (UPB), Batam, Kepri, Indonesia \\ Nurma@puterabatam.ac.id
}

\begin{abstract}
The aim of the study was to identify and analyze the types of presupposition implied in the BBC news of corona virus in Indonesia. In this research, the researchers used descriptive qualitative research as the research design. The research design was conducted to design is a qualitative approach in which express the outcome in words and provide an explanation of the result. In collecting the data, the researchers used the observational method and non-participatory technique by Sudaryanto (1993). In analyzing data, the researchers applied pragmatic identity method and distributional method. As for the theory, the researchers used the presupposition theory proposed by Yule (1996). The types are existential, factive, non- factive, lexical, structural and the counter factual presupposition. The research was existing in the BBC news "Indonesia corona virus". The research found the types of presupposition are existential, factive, non- factive, lexical, structural and the counter factual presupposition. The most type of presupposition which could be found is existential presupposition.
\end{abstract}

Keywords : news, presupposition, types presupposition

\section{INTRODUCTION}

People need language to share information and build relationship with each other as a manifestation of social being. Language and communication are things that people need to communicate with other people (Julius \& Ambalegin, 2021). In a conversation information is important, when the speaker and writer assumes information to the listener and reader 
although the inforamation is not easy to understand, because the implication is not easy to get the meaning. The listeners need time to think about the word meaning in the same situation with what the speaker means, and they need assumption to get the meaning from speaker. Pragmatics concerned in studying the meaning as communication which used by speaker to the hearer (Yule, 1996).

Presupposition is one part of pragmatic, the utterance meaning that accepted by hearer or reader. The phenomenon of presupposition exists in middle of conversation. Presupposition means that every utterance produced by the speaker and listener obtains information and provides assumptions about the activities conveyed by the speaker. The information that the hearer got means the process of presupposition. The hearer looks for facts and thinks about the possibilities of the utterance to get the interaction of information messages. Presupposition is certain a word that the speaker assumes previous case to make an utterance. There is an example of assumption phenomenon presupposition in mutual language.

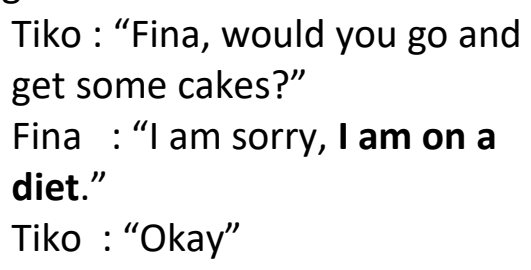

From the conversation above the reader or listener can take mutually known presopposition 'Diet' means. Based on the conversation, the underlined utterance's meaning is to refuse to eat the cake (prohibited to eat cakes). We can take semantic point of view that Fina refuses the invitation by Tiko, and Tiko can know what the meaning of Fina said. You presuppose that the woman takes care of her dietary habit.

The instance of presupposition can be found in the CNBN Indonesia. An article in the news has function to know the phenomenon using presupposition, one of phenomena that will be found in the sentence in the BBC news about Indonesia corona virus:

"The government's decision to free the COVID-19 vaccine is a positive step to encourage public optimism to return to activities and drive the economy while still implimenting health protocol." (CNBC Indonesia, 2020)

In the statement presupposition above is included in lexical presupposition. It is because it was expressed in implied manner so that the information of the statements of utterance can be obtained after the statement of the utterance. The utterence gave an assumption to solve economic problem that giving free covid-19 vaccination progamme is one of method to stop the spread of the virus.

Based on the theory above the researchers found two previous research which discussed presupposition related to the utterence from speaker in dialogue from movie. First research came from Sukmawati (2020). The researcher discussed about presupposition from Wonder Women movie by using theory of Yule (1996) in order to analize presupposition and the types of presupposition that higest presentage was exstential presupposition with 55 data or $46,65 \%$, second was factive presupposition with 31 data or $26,3 \%$, and third was 
structural presupposition with 17 data or $14,4 \%$ from 118 data that writer find on this movie.

Second research that disscused presupposition was the research of Yosi, Kristi and Deliana (2020). The researchers discussed about presupposition found in the Movie "Beauty and the Beast". The research used theory from Yule (1996) and Saeed (1997) in order to analize presupposition and types of presapposition was used 26 times of total uttereces, ten factive was used 9 times, whereas lexical and structural presupposition same fequance in 8 times , and non - factive presupposition was four times and counter factual presupposition in 3 times.

Both previous research above dissused same thing that is presupposition from dialogue movie. The difference between two journals above is both used presupposition not only concern about the dialogue but also the situations of dialogue of the conversation to related with the meaning to the context. In addition, this present research also used the same theory from Yule (1996). This research aimed at identifying and analyzing the types of presupposition implied in the BBC news of corona virus in Indonesia.

\section{LITERATURE REVIEW}

\subsection{Presupposition}

Presupposition escape in the middle of conversation refers to assumption from the speaker to the listener to get information obtained from understanding (Hudson, 2000). In other words, there is informatin refers to assumption made by speaker and listener which are benefits for the good interpretation of utterance (Yule, 1996). According to Saeed (1997) presupposition are produced part of contraction, and particular word to express an idea to giving the information. Yule (2010) said that presupposition has been associated part of large number of words, phrases and structers. The linguistic forms are included to be factors of potiantial presupposition which can become actual context in presupposition. And then he states the six types of presuppositions, those are:

\subsubsection{Existential presupposition}

Exsential presupposition is an assumption to express the existance of the named by the speaker. This type of presupposition is also giving information in any definite noun phrase. Example :

"Tracy's brother's car." (Yosi,Kristy \& Deliana, 2020)

(Tracy has a brother)

This statement presupposes and shows that Tracy and her brother escape. The speaker may also give specific assumption about both of them that she has brother and her father has a lot of money because he has a car, a car is expensive.

\subsubsection{Factive presupposition}

An assumption to show something can be tend as a fact using some verbs that are "realize", " aware", "know", "glad" and "regret". This presupposition use of the speaker to make the hearer believe of the fact information one part of the sentence. Example : 
"She did not realize he was ill." (Yosi,Kristy \& Deliana, 2020)

( He was ill)

In the sentence above, the part of sentence that showing about his true condition "He was ill" because this condition is fact and must be true to make the sentence and giving information.

\subsubsection{Non - factive Presupposition \\ Non factive presupposition} associates with some verbs which are considered not be the fact. People often use verbs such as "dream, "pretend" and "imagine' to suppose the following is not true. Example :

"I dreamed that I was rich." (Yosi,Kristy \& Deliana, 2020)

( I wasn't rich)

In the example above, the speaker giving information about verb of " dreamed" and clause sentence "I was rich" it means is not true because using verb "was" this is shown only in her dreamed is not fact.

\subsubsection{Lexical presupposition}

Lexical presupposition is an assumption that speaker uses one form with affirmation. The meaning is the interpreted conventionaly with another meaning, such as "start", "again" and "stop". In this part of speech certain expression are used by the speaker to presuppose another concept. Example :

"He stopped smoking." (A'la \&

Zakrimal, 2019)

( He used to smoke)

In the example above had shown of verb " stopped" it means presupposition in the past he is smoking and now he stopped smoking, is not smoking again.

\subsubsection{Structural presupposition}

Structural presupposition is an assumption related to the use of certain words and phrases. In this words, consist of sentence structures have been conventionally analyzed and regularly presupposes that part of the structure is assumed to be true. Example :

"Where did you buy the bike?"

(Yosi,Kristy \& Deliana, 2020)

(You Bought the bike)

The example above shows that the listener perceives the information presented is true information than just the assumption of the person asking the question. In addition, when asking a question the speaker also presupposes something real to give information.

\subsubsection{The counter factual presupposition \\ A counter - factual preposition is} the assumption that pressuposed is not only untrue, but also is the opposite of what is the true or include of fact. Example :

"If you are my friend, you would have helped me." (Siahaan \& Mubarak, 2020)

(You are not my friend)

The sentence above presupposes that the information showed about the clause is not true at that time. In other words, the example of presupposition you are not my friend means you did not help me when I got problem, this is conditional sentence structure of the type is generally called counter-factual conditional.

\section{RESEARCH METHODOLOGY}

This research used the descriptive qualitative method which collected the data by observating the data source. 
According to Arikunto (2010), descriptive research is the study intended to investigate the condition, situation, events circumstances, and other activities, and the result presented in the form of the research report. It means that the data in this research are analyzed by collecting, grouping, analyzing, and interpreting the research data. The data sources used in this study are secondary data sources. Secondary data can be obtained from supporting libraries such as textbooks, journals, documentation, research institute data and relevant agency data. Data collection techniques through literal studies (library research). Literature study is done by collecting data in the form of secondary data related to topics and problems related to presupposition in the news.

This research was arranged by non-participant observation. After collecting the data, the researchers took next step that is analyzing the data. The process of analyzing the data is carried out after all the data has been collected. Data analysis is done by reading, studying, reviewing and comparing various library sources and interpreting the results of the analysis, so that it can answer all the problems.
The last stage is to draw conclusions from the problems that have been answered. According to Sudaryanto (2015), there are two methods for analyzing the data, they are pragmatic identity method and distributional method. In this research, pragmatic identity method was used to analyze the meaning of the utterance, while distributionall method was used to analyze the type. Then, the researchers presented the result. There are two methods to present the analysis of the data that was found (Sudaryanto, 2015). The methods are formal and informal method. The result of this research was presented informally, because the result was arranged in the form of words.

\section{FINDINGS AND DISCUSSION}

\subsection{Findings}

There was found 24 data of presupposition in BBC news: Corona Virus in Indonesia. The researcher presented only ten data from the total in the discussion section in order to avoid too much repetition of information about the sama type of presupposition and aim to present the data more effectively.

No Types of Presupposition

Frequency

\begin{tabular}{clcc} 
& & Number & Precentage \\
\cline { 3 - 4 } $\mathbf{1}$ & Existential Presupposition & 19 & $79,167 \%$ \\
$\mathbf{2}$ & Factive Presupposition & 1 & $4,167 \%$ \\
$\mathbf{3}$ & Structural Presupposition & 2 & $8,333 \%$ \\
$\mathbf{4}$ & The Counter Factual Presupposition & 2 & $8,333 \%$ \\
& & 24 & $100 \%$ \\
\hline
\end{tabular}

4.2 Discussion

4.2.1 Existential Presupposition Data 1
"President Joko Widodo, 59, was the first person in the country to receive the vaccine shot on Wednesday. Vice-President Ma'ruf 
Amin, 77, will not get the jab early as he is too old."

Presupposition:

-There is a President, named Joko Widodo.

-There is a Vice-President, named Ma'ruf Amin.

Based on the utternace, it shows that the existential presupposition is included. It is because the utterance above contains the existence of the entities that named by the speaker. The entities are Joko Widodo as a President and Ma'ruf Amin as a Vice-President.

Data 2

"Professor Amin Soebandrio, who is on a board that has advised the government on its "youth first" strategy, argues that it makes sense to prioritise immunising working people."

Presupposition:

-Professor Amin Soebandrio exists.

-There is a strategy, called youth first.

In the utterance, it presents a type of pressupotition called existential presupposition. The presupposition was presented because the utterance contains the existence of the entities that named by the speaker.

\section{Data 3}

"Sendy, a 33-year-old mother, was worried that her child would also be exposed to Covid-19."

Presupposition:

-Sendy exists and she has a child.

-Covid-19 exists.

The presuppositions above are included existential presupposition. It is because the utterance includes the existence of the entities that named by the speaker and indicated by possessive construction "her".
Data 4

"Immunising the working members of a household will mean they are not bringing the virus into the home, where their older relatives are," said Dr Siti Nadia Tarmizi, the Ministry of Health's spokesperson for the Covid-19 vaccination programme."

Presupposition:

-The working members exist and they have older relatives.

-The virus exists.

-There is a Ministry of Health's spokesperson, named $\mathrm{Dr}$ Siti Nadia Tarmizi.

-There is a Covid-19 vaccination programme.

From the utterance above, it is clear that the existential presupposition is involved. The reason is that the utterance contains the existence of the entities that named by the speaker and indicated by possessive construction "their".

\section{Data 5}

"The Indonesia Ulema Council or (MUI), whose job it is to decide such things, held long discussions and after an in-depth audit, it announced that the Sinovac vaccine is halal."

Presupposition:

The Indonesia U-lema Council or (MUI) exists.

-Sinovac vaccine exists.

The presuppositions above presented the existential presupposition. The reason is that the utterance presents the existence of the entities that named by the speaker. The pressuposition are in accordance with the Indonesia Uleman Council and Sinovac. 


\subsubsection{Factive Presupposition}

Data 6

"We know its real efficacy and be able to compare it with other vaccines."

Presupposition: It (the vaccine) has

efficacy and be able to be compared with other vaccines.

In the utterance above, it appears the verb "know" that indicates that something which is fact and it gives the information to other people.

\subsubsection{Structural Presupposition}

Data 7

"Why do children get exposed?"

Presupposition: The children get exposed.

The question above shows that the listener or reader perceives that the information presented is true information than just the assumption of the person asking the question. In addition, when asking a question the speaker also presupposes something real to give information.

\section{Data 8}

"Why target young working

\section{adults?"}

Presupposition: The target is young working adults.

The question above shows that the listener or reader perceives that the information presented is true information than just the assumption of the person asking the question. In addition, when asking a question the speaker also presupposes something real to give information.

\subsubsection{The Counter Factual Presupposition}

Data 9

"But even if they had been asked to test it on people over 60 , she would say they mostly likely be still focused on immunising the working population first."

Presupposition: They hadn't been asked to test it on people over 60, and she would not say they mostly likely be still focused on immunising the working population first.

The statement above is generally called counter- factual conditional. It presupposes that the information in the if-clause is not true the time of utterance.

\section{Data 10}

"If the mother has been vaccinated, the antibodies will decrease to her child."

Presupposition: The mother has not been vaccinated, and the antibodies will not decrease to her child.

Based on the statement above, it indicates that the counter-factual conditional appears. It presupposes that the information in the if-clause is not true the time of utterance.

\section{CONCLUSION}

After analyzing the types of presupposition in BBC news, it can be concluded that the most frequent type of presupposition used is existential presupposition, which is used in the 19 data found. It appearence shows a precentage of almost $80 \%$ of the total data found. Then, the structural presupposition and counter-factual presupposition which are used in each of the two data presented. Meanwhile, another type of presupposition used less frequently in the news is factive presupposition, which only found in one data presented. Existential presuppositions appear frequently in 
the $B B C$ news. This shows that the presuppositions that consider the existence of something that indicates ownership or the existence of a statement in speech are more commonly found in data sources.

\section{REFERENCES}

A'la, S., \& Zakrimal. (2019). An analysis of presupposition in "Ouija: Origin of Evil movie": Pragmatics Approach. 13.

Arikunto, S. (2010). Prosedur penelitian suatu pendekatan praktik. Jakarta: Rineka Cipta.

Bekalu, M. A. (2006). Presupposition in news discourse. Discourse and Society, 17(2), 147-172. https://doi.org/10.1177/09579265 06060248

Capone, A. (2017). Presuppositions as conversational phenomena. Lingua, 198, 22-37. https://doi.org/10.1016/j.lingua.20 17.06.014

CNBC Indonesia. (2020, December 17). Vaksin Covid-19 gratis, optimisme pemulihan ekonomi meningkat. CNBC Indonesia. https://www.cnbnindonesia.com/n ews/20201217085705-8209673/vaksin-covid-19-gratisoptimisme-pemulihan-ekonomimeningkat

Colomina-Almiñana, J. J. (2018). Pragmatic presupposition and unarticulated constituents. Lingua, 206, 112-126. https://doi.org/10.1016/j.lingua.20 18.02.003

Julius, J., \& Ambalegin, A. (2021). Negative Politeness strategies used by main character in "The Imitation" Movie. Jurnal Ide Bahasa, 3(2), 81-92.
Kristy, Y., Deliana, D., \& Harefa, Y. (2020). Presupposition in Beauty and the Beast movie Script. Language Literacy: Journal of Linguistics, Literature, and Language Teaching, 4(2), 375-383. https://doi.org/10.30743/Il.v4i2.27 52

Saeed, J. I. (1997). Semantics. Malden: Blackwell Publisher Inc.

Siahaan, C., \& Mubarak, Z. (2020). An analysis Of presupposition found In the Guardian news: pragmatical approach. JEE (Journal of English Education), 6(1), 1-8. https://doi.org/10.30606/jee.v6i1. 405

Sudaryanto. (2015). Metode dan Aneka teknik analisis bahasa (Vol. 34, Issue 2007). Yogyakarta: Duta Wacana University.

Sukmawati, S. (2020). Presupposition As Found in Wonder Woman Movie : a Pragmatics Analysis. 18. http://eprints.ums.ac.id/id/eprint/ 80096

Yule, G. (1996). Oxford Introductions to language study - Pragmatics. In Pragmatic (p. 76).

Yule, G. (2010). The study of language (4th ed.). New York: Cambridge University Press. 